matters that scarcely need to be referred to a special advisory board.

Of any far-reaching advisory purpose, of any great original directive enterprise, of anything in the nature of spontaneous movement, this report shows no record; one looks in vain for any reference to scientific education, or even for a connected account - as contrasted with bald, disjointed departmental summaries-of the general progress of science in India, vital affairs in which a Board of Scientific Advice might be expected to exercise a missionary influence, if not to take a commanding lead.

The simple fact is that, so far as the advisory business goes, this Report of the Board of Scientific Advice for India is a document of the ex officio genus; and it can scarcely be otherwise when the President of the Board is merely an ex officio hierarch of the Indian Secretariat, instead of being a man of science specially selected for his critical knowledge of scientific affairs.

\section{ELIAS METCHNIKOFF.}

$\mathrm{O}$ $\mathrm{NE}$ of the most remarkable figures in the scientific world passed from among us on

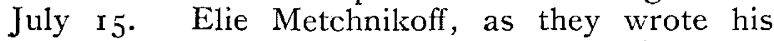
name in France, his adopted home, stands out as the type of a gifted, indefatigable investigator of Nature who, in accordance with his beautiful and earnest character, never faltered in his career, but from his boyhood onwards devoted himself to the minute study of animal life, and by a natural and as it seemed inevitable process passed through the study of the microscopic structure and embryonic growth of simple marine organisms to the investigation of human diseases and his great discoveries of the nature of the process known as inflammation and of the mechanism of "immunity" to infective germs and the poisons produced by them. By every zoologist in the world he was especially honoured and revered; for it was to him that we owed the demonstration of the unity of biological science and the brilliant proof of the invaluable importance to humanity of that delightful pursuit of the structure and laws of growth and form of the lower animals which he and we had pursued from pure love of the beauty and wonder of the intricate problems of organic morphology.

Just as his chief and friend, the great Pasteur, was privileged to proceed directly and logically in his own life's work, by his genius and insight, from the discovery of astonishing new facts as to crystalline structure-which seemed to have no bearing on human affairs - to the understanding (by the aid of those discoveries) of fermentation and infective disease; so did Metchnikoff himself both discover the activity and universality of the organic cell-units which he called "phagocytes," and at once proceed to demonstrate their prime importance in the process known as inflammation and the understanding of "immunity," which has revolutionised medical theory and practice.

Elie Metchnikoff was born in 1845 at Ivanavka, near Kharkoff. His father was of Moldavian NO. 2439, VOL. 97] ancestry and an officer of the Imperial Guard, from which he retired with the rank of majorgeneral. He was devoted to the pursuits of a country gentleman, among which horse-racing was his special favourite. He had no tendencies to scientific study. Elie's mother, whose family name was "Nevakovitch," was a Jewess. He owed his mental gifts largely to her. From childhood he showed a strong taste for the study of Nature. After passing through the high school of Kharkoff he entered the university at the age of seventeen and completed his degree examinations in two years, when he went off (in 1864) to Germany for further biological training. He had already, in 1863 , when he was only eighteen, published a paper in Reichert's Archiv on the stalk of Vorticella, and another on the nematode Diplogaster. In 1864 he published some observations on the Acinetarian Sphærophrya. After a brief sojourn in Heligoland he went to work in Leuckart's laboratory at Giessen, and accompanied the professor to Gottingen when the latter was promoted to that chair. In Leuckart's laboratory he worked at the parasite of the frog, Ascaris nigrovenosa, and made the important discovery of the fact that the hermaphrodite parasite of the frog's lung hatched from eggs gives birth viviparously to a free-living generation of males and females. This he published in $186_{5}$ in Reichert's Archiv, and a translation of his paper appeared in the Quarterly Journal of Microscopical Science in 1866 . Leuckart claimed to have made the discovery "with the assist. ance of Herr Mecznikow," but Metchnikuff briefly stated that this was erroneous and that he alone had done the work in the absence of Prof. Leuckart and withsut his aid or suggestion. Naturally this terminated their friendly relations. In the same year he published some notes on those little-known microscopic animals, Icthydium, Chætonotus, Echinoderes, and Desmoscolex. This also was translated for the Quarterly Journal in 1866 , and thus I became familiar with his name and the interesting character of his work, though I did not make his personal acquaintance until twenty-two years later, when (in I888) Pasteur introduced me to him in his laboratory in the rue Vaugirard.

These papers were rapidly followed in 1866 by others showing his first-rate powers of accurate observation and originality, viz. on a European land Planarian; on the development of Myzostomum, the ecto-parasite of the feather-star, which he showed to be a modified Chætopod; on insect embryology (Hemiptera and Diptera); on the remarkable new rotifer, Apsilus lentiformis; and on the viviparous reproduction of the larvæ of the fly Cecidomyia. Then he sojourned for a time (1867) at Naples (before the days of Dohrn's Zoological Station) and wrote on the embryology of the cuttle-fish Sepiola, on the strange marine forms Chætosoma and Rhabdogaster, and in 1869 on Tornaria (which he showed to be the larva of Balanoglossus) and on the embryology of Echinoderms and of jelly-fish.

In 1870 he was appointed professor ordinarius 
of zoology in the University of Odessa, and soon afterwards published papers on the embryology of Chelifer and of Myriapods. In the previous year he published an interesting paper on the little nematode parasite of fishes' gills-Gyrodactylus-and joined with that fine naturalist, Claparede, whom he met at Naples, in a paper on the embryology of Chætopods.

After his appointment at Odessa his work was interrupted by the illness and death from tuberculosis of his first wife, whom he had married in r868. In spite of every care and a long sojourn in Madeira, whither he accompanied her, she died there in 1873 . But in 1874 we find a paper by him "On the Eyelids of Mongolians and Caucasians," of considerable value to anthropologists, and in 1877 one of a bionomic character on "The Struggle for Existence between Two Species of Cockroaches-.-Periplaneta orientalis and Blatta germanica."

In 1875 he married his second wife, Olga Belocoyitoff, who was only seventeen years of age. She had just completed her studies in the "lycée" of Odessa, and attended after her marriage her husband's zoological teaching in the university. She survives him, and was his constant companion and ceaselessly devoted friend and helpmeet. She often aided him in laboratory work and by her knowledge of English and other languages, though her own special gifts, which she has cultivated to a high degree of excellence, are in painting and sculpture. From time to time she has published her own contributions to subjects which were occupying her husband's attention. The earliest of these is one "On the Morphology of the Pelvis and Shoulder-girdle of the Cartilaginous Fishes," published in th:? Zeitsch. wiss. Zoologie, r88o.

Metchnikoff holds an important place beside his great fellow-countryman and intimate friend, Alexander Kowalewsky (who died some years ago), in the establishment of what may be called cellular embryology and the investigation of the early stages of development of invertebrata by following out the process of cell-division and the arrangement of the early formed cells in layers. In the twelve years 1875 to $\mathrm{I} 886$, when his last embryological paper was published, he produced many important memoirs on cellular embryology -namely, on that of calcareous sponges (in which he showed that the inner and outer primitive layers had been transposed in regard to their origin by Haeckel and Miklucko-Macleay); on that of jelly-fishes, of Planarians, of Echinoderms, of Ctenophora, and of Medusæ. These were accompanied by important theoretical discussions and suggestions as to the ultimate ancestral origin of the endoderm and the mesoblast. He also wrote on that curious group of minute parasites, the Orthonectids, and on insect diseases.

But the new departure in his fruitful career was approaching. It grew out of his observations on living jelly-fishes and sponges and on the transparent marine embryos of Echinoderms and the transparent floating mollusc Phyllirhoe. In 1882 , owing to political disturbances in the University of Odessa, Metchnikoff migrated to Messina, the harbour of which is celebrated among zoologists for its rich fauna of transparent floating larvæ and adult glass-like Pteropods and jelly-fishes. Here he developed his views, already foreshadowed in I880 (Zoolog. Anzeiger), on intracellular digestion exhibited by the amoboid cells of animal organisms, and published a series of papers in which the name "phagocyte" is first applied to these cells. In this, as in similar cases of discovery, neither Metchnikoff himself nor any of his friends claimed that he was the first to observe all the facts leading to his generalisation. $\mathrm{He}$ was not the first to witness the ingestion of foreign particles, of fragments of dead tissue, and even of bacteria, by the amœba-like cells of the animal body. He knew and cited the early observations of Haeckel on the ingestion of pigment granules by the amoeboid blood-corpuscles of the sea-slug Tethys. He knew and cited the numerous observations on the activity of large amoboid cells in assisting the resorption or rapid destruction of other tissues in some special instances. He knew the observations of Jeffrey Parker and others on the intra-cellular digestion of food particles taken into their substance by the endoderm cells lining the digestive cavity of Hydra. He knew Koch's observation of bacilli within a colourless vertebrate blood-corpuscle, attributed by that observer to the active penetration of the blood-corpuscle by the aggressive bacilli. These and other like instances were all regarded as exceptional by their observers and not interpreted as evidences of a definite and universal activity of the amceboid cells of large physiological significance. Metchnikoff was acquainted with the remarkable discoveries of Cohnheim, Stricker, and others (in some of which I had a pupil's share during my stay in the winters of $1869-70$ and I870-7 I at Vienna and Leipzig respectively). The pathological laboratories were full of observations and talk about the "diapedesis" and "outwandering " of the amœboid corpuscles in inflamed tissues, the origin of pus-corpuscles, and the activity of the amoeboid cells in the stellate cavities of the frog's cornea and other connective tissues when stimulated. Metchnikoff put two and two together, and formulated the proposition that in all multicellular animals the main function of the cells derived from the deep or mid-embryonic layer between the dermal and intestinal lining layers is nutritional, and that they possess the power of ingesting and digesting - as does an amœba-solid particles, whether such particles are introduced from the outside or are parts of the organism which, owing to one reason or another, must be broken up and removed. The amoboid cells in connective tissues and in the blood and lymph are such eater-cells or phagocytes, as he now termed them.

He at once proceeded to explain the significance of these phagocytes and their utility to the organism, not only by pointing to their work as scavengers removing injured and dead tissue, to which

NO. 2439, VOL. 97] 
they are brought in hundreds of thousands by the process known as inflammation, but he also inmediately gave first-class importance to their recognition by connecting them with Pasteur's great discoveries as to the cause of infective diseases by poisonous "microbes" which intrude into previously healthy organisms, and he further connected his generalisation with Darwin's theory of the origin of species by the natural selection of favoured races in the struggle for existence. He published in I884 an essay entitled "The Struggle of the Organism against Microbes," in which he maintained the thesis that the phagocytes, universally present in multicellular animals, have been developed and established by natural selection in the animal organism as a protection against intrusive disease-causing bacteria.

He was able in 1884 to observe and give illustrative drawings of a demonstrative case of the activity of the phagocytes in the blood of a transparent fresh-water flea (Daphnia) when it was infected by a yeast-like parasite called Monospora. This parasite frequently makes its way into the blood of the water flea and, multiplying there, often causes death. Metchnikoff watched with his microscope and made careful drawings of the phagocytes as he saw them in the living flea engulfing and digesting the intrusive Monospora. In some cases the phagocytes, in others the Monospora, got the upper hand. Later when I knew him he had a small aquarium dedicated to the cultivation of these demonstrative water fleas and their infective microbe.

Having now determined to give up his zoological and embryological researches in order to devote the rest of his life to the development of his doctrine of "phagocytosis," Metchnikoff accepted the invitation to become director of a new bacteriological laboratory at Odessa, but, finding the conditions there not favourable to his special work, he relinquished the post in 1888 and, having fortunately been cold-shouldered in Berlin, came to Pasteur in Paris, who, thoroughly appreciating the value of his work, gave him a laboratory and every facility for his investigations in his own institute, at that time located in the Ecole Normale, rue Vaugirard. When a few years later the Institut Pasteur was built in the rue Dutot Metchnikoff was given a fine suite of laboratories, lecture-room, and space for keeping animals, and became sub-director of the institute a few years ago.

Young investigators now came in growing numbers to Paris in order to work in Metchnikoff's laboratory, and he pursued with triumphant success, but not without opposition and sometimes insult from the older and more ignorant medical men, the establishment of his views as to the essential importance of "phagocytosis" in resistance to disease. Among his more fatuous opponents was a prominent English pathologist who scornfully alluded to his views as "Metchnikoffism."

In 1892 he produced as an illustrated volume, with the title "The Comparative Pathology of InNo. 2439, VOL. 97] flammation," the substance of a course of lectures delivered at the Institut Pasteur. It is one of the most delightful examples of scientific method conceivable. It is essentially a careful and logical presentation of minute observations arranged so as to bring before the reader the evidence in favour of his argument. He invariably followed this method in the controversies in which he necessarily engaged. He never recriminated; he never cited mere authority nor endeavoured to falsify his opponent's statements by "smart" word-play. He simply made new experiments and observations suggested by his adversary's line of attack, and so practically smothered him by the weight of honest, straightforward demonstration of fact. He showed that in the lower animals the phagocytes are attracted in hundreds by "chemiotaxis" to intrusive or injurious bodies which occur in the tissues, and then either enclose or digest them. He proceeded to show that in the vertebrates, where the immense network of the blood-vessels is under the control of the nervous system, "inflammation" is set up as a curative process, and that the elaboration of its mechanism has been established by natural selection. A local arrest of the blood-stream is produced by the nerve-control of the vascular system, resulting in the out-wandering from the now nearly stagnant blood of phagocytes chemically attracted to an injured spot, where, arriving like an innumerable crowd or army of scavengers, they proceed to engulf and digest tissue which has been killed by injury, and similarly to isolate or to destroy and digest injurious intrusive substances, prominent among which are infective poisonous bacteria.

Metchnikoff thus finally and conclusively "explained" the process called "inflammation." His attention and that of his pupils was now given for some years to the great question of "immunity." How is it that some individuals are either free from the attacks of parasitic micro-organisms to which their fellows are liable, or, if attacked, suffer less seriously than others do? To answer this question is to go a long way to the solution of the great practical question as to how to produce immunity to infective disease in man. It involved the investigation of the chemical activities of the phagocytes, to the knowledge and theoretical understanding of which a great number of highly gifted leaders of experimental inquiry-to name only Ehrlich, Behring, and Almroth Wright -have contributed in the most important way. It is impossible on this occasion to enumerate or even indicate the large series of investigations and records of experiment now continuously produced by Metchnikoff or by assistants under his immediate supervision. The Annales de l'Institut Pasteur are largely made up of these records and discussions. In IgOI Metchnikoff produced his great book on "Immunity in Infectious Diseases," an English translation of which was at once published. The subject branched out into various lines, such as are indicated by the names serotherapy, toxins and anti-toxins, hæmolysis, opso- 
nins, and bacteriotropins. It must suffice here to state that Metchnikoff successfully established the doctrine that it is to the healthy activity of our phagocytes that we have to look not only for temporary protection, but for immunity against the micro-organisms of disease.

Since I9OI-until he fell ill last winter-Metchnikoff was incessantly active in his laboratory, working there from early morning until evening, when he took train to his country house on the heights above the Seine. Rarely would he tear himself away from his absorbing work to enjoy a holiday. He went a few years ago to Astrachan, on the Caspian, to inquire for the Russian Government into the occurrence of bubonic plague in that region, and studied also the incidence of tuberculosis in the town populations and among the Kalmuck Tartars. On the latter subject he gave (in response to my urgent request) a valuable lecture in London before the National Health Society (in r912), and on other occasions he made short visits to this country in order to receive hornours and deliver special dis. courses-as at the Darwin celebration at Cambridge in I909. The variety of infective diseases to the experimental investigation of which he turned the resources of his laboratory and his theoretical conceptions is truly astonishing. As late as IgI I he wrote: "Perhaps before long it will be possible to explain diabetes, gout, and rheumatism by the injurious activity of some variety of microbe" (preface to the invaluable volume, "Microbes and Toxins," by Dr. Etienne Burnet, published in London by Heinemann).

In 1903 he found time to write a profoundly interesting popular book, "The Nature of Man" (London: Heinemann), in which, among other things, he discourses of old age, and his view that unhealthy fermentation commonly occurring in the large intestine produces poisons which are absorbed, and lead to deterioration of the tissues of the walls of the arteries, and so to senile changes and unduly early death. He satisfied himself, experimentally and clinically, that the use of "sour milk" as an article of diet checks or altogether arrests this unhealthy fermentation in the intestine by planting there the lactic bacillus which, forming lactic acid, renders the life and growth of the bacteria of those special poisonous fermentations (which cannot flourish in an acid environment) impossible. Hence he himself daily took a pint or so of sour milk, and he recommended it to others and arranged for the commercial preparation of a particularly pure and agreeable "sour milk," from the sale of which he scrupulously abstained from deriving any pecuniary profit. This small, though valuable, adventure of his in dietetics has been-unfortunately, but perhaps inevitably-the one and only feature of his long career of vast scientific discovery which has impressed itself on the somewhat erratic intelligence of the "man in the street."

Metchnikoff was a foreign member and Copley medallist of the Royal Society, a member of the Institute of France, of the Academy of Sciences of Petrograd, and of many other societies. In Igo 8 he was awarded the Nobel prize for his researches on immunity, and he received only a fortnight before his death the announcement that the Albert Medal of the Society of Arts of London had been this year awarded to him in view of the benefit to humanity of his scientific discoveries.

I cannot close this imperfect survey of the impressive and ideally complete career of my friend without some few personal notes. From the day when I met him in Pasteur's laboratory in I888 we became warm friends. $\mathrm{He}$ was singularly simple, genuine, and unaffectedly good and unselfish. I could tell a hundred tales of his benevolence and humane spirit; of the unrecorded charitable aid given by him and his wife to the poor of Paris and to expatriated Russians; of his exquisite politeness and consideration to all those who were his servants. I am convinced that the devotion of the latter half of his life to the solution of the problems of disease was due to his goodness of heart and his ardent desire to alleviate human suffering. He never was a smoker, and twenty years ago gave up the use of alcohol entirely. He had no taste for sport of any kind, and never indulged in "recreations" or "amusements" or big social functions. $\mathrm{He}$ was a devoted lover of music, and had much knowledge of art and many friends in the great art world of Paris. His beard was large and his hair long, and he was thick-set and muscularly strong, though he becarne more and more bent, as the years went on, by his constant stooping over the microscope. No year passed, after I first knew him, without my spending some time with him and Madame Metchnikoff in Paris or in their home at Sèvres, and on several occasions he has stayed with me in London or earlier in Oxford. From time to time he has shown to me the experiments and microscopic evidence upon which his own and his pupils' discoveries were based, and has put before me the preliminary hypotheses by aid of which he was seeking-as opportunity offered-to arrive at further knowledge of appendicitis, syphilis, the yaws, infantile paralysis, green diarrhœa, cholera, tubercle, cancer, diabetes, gout, and rheumatism. Only three years ago he carried out some new researches on a zoological subject-the natural removal of black pigment from the wing-feathers of gulls-which he proposed to publish in the Quarterly Journal of Microscopical Science. But the terrible events of the last two years put such work out of his power. In his last moments he insisted very urgently that an immediate autopsy should follow his death. He had suffered for six months from pneumonia, pleurisy, and latterly bronchitis. The autopsy showed atheroma of the aorta and related cardiac disease. Metchnikoff died in the apartments of the Institut which had been assigned as a dwelling to Pasteur. According to his wish, his remains have been incinerated, and the urn containing his ashes will be placed in the library of the Pasteur Institute.

E. Ray Lankester.

No. 2439, VOL. 97] 